\title{
Domestic violence: The day-to-day life of Peruvian women experiencing depressive disorders
}

\author{
Josefina Amanda Suyo-Vega *, Mónica Elisa Meneses-La-Riva, Susana Edita Paredes-Díaz, \\ Víctor Hugo Fernández-Bedoya \\ Universidad César Vallejo. \\ Av. Larco 1770, Trujillo 13001, Peru. \\ jadasa71@gmail.com \\ * Corresponding Author
}

\section{ARTICLE INFO}

\section{Article History}

Received:

5 May 2020;

Revised:

7 May 2020;

Accepted:

12 August 2020

\section{Keywords}

Domestic violence; Depressive disorders; Women;

Peru

\begin{abstract}
Violence against women in Peru is on the rise, with $138 \%$ of femicides recorded by women's emergency centers by 2018. Mental health with depressive disorders is the leading cause of health problems worldwide, according to the World Health Organization (WHO). The objective was to determine the prevalence of domestic violence and depressive disorders among women in three departments of Peru. The methodology was applied, with a quantitative approach, of non-experimental design, of a cross-sectional nature. The population consisted of 384 women over 18 years of age, distributed in Lima 250, La Libertad 80, and Amazonas 54, where they reported mistreatment and depressive disorders, information recorded in the Women's Emergency Centres, the police stations, the Vaso de Leche social programs, the canteens and the Office of the Ombudsman for Women, Children, and Adolescents. The data collection technique was a survey, the instruments applied were two questionnaires, one measuring the prevalence of domestic violence (VIF J4), and the Hamilton Scale for depressive disorder, which suggests the following cut-off points: not depressed, mild/minor depression, moderate depression, severe depression, and very severe depression. Among the relevant results, it was found that of the $100 \%$ of women who suffer from domestic violence, these are subdivided into physical violence $16 \%$ ), psychological violence $20 \%$, sexual violence $26 \%$, social violence $16 \%$, patrimonial violence $11 \%$ and gender violence $13 \%$. For the depressive disorder, it was found that 100 percent of women who suffer from domestic violence have depressive disorders divided into intermediate insomnia $4 \%$, early insomnia $7 \%$, late insomnia $7 \%$, women who suffer in the development of their activities and work $8 \%$, depressive mood $14 \%$, thoughts about suicide (15/100), psychomotor inhibition 15\%, and psychomotor agitation $15 \%$ that concluding that domestic violence associated with depressive disorders leads to suicide.
\end{abstract}

\begin{tabular}{|c|c|}
\hline 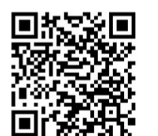 & This is an open access article under the $\mathrm{CC}-\mathrm{BY}-\mathrm{SA}$ license. \\
\hline
\end{tabular}

\section{INTRODUCTION}

In countries of the Americas, violence against women has recently increased, with $60 \%$ of women suffering abuse or some violence. One study has reported the prevalence of physical and sexual violence inflicted by a partner at some point in their lives (Pan American Health Organization, November 29, 2018). The most dangerous place for a woman is her home. Their partners murdered most female homicide victims. Some countries are establishing new legal strategies and social 
programs that have not made progress to date. According to Zraick (2018), likewise, the European Union and the United Nations took action to combat femicide in Latin America. Still, it finds that, to date, there is no standardized definition, and there is a difference in the execution of the legal part.

Currently, the rates of violence against women have increased over previous years, as 14 cases have registered, representing a 40 percent increase to January 2018. All countries except Mexico budget funds to tackle violence against women. Thus, it cannot say that violence against women is being combated (United Nations Economic Commission for Latin America and the Caribbean, 2019). On the other hand, the domestic violence environments that women suffer have produced mental health problems such as depressive disorders. Depression is conceptualized as a frequent mental disorder characterized by the presence of sadness, feelings of guilt, lack of concentration, among others, reaching extreme states such as suicide (World Health Organization, 2018).

Statistical reports produced by women's emergency centers show that 379 women were murdered in Lima and 55 in La Libertad in 2009-2019, and 13 in Amazonas. Most of the women who suffer violence are adults, $83 \%$ of whom are between 18 and 24 years old. The victim of femicide is 59 years old and has one to three children. Most cases involve stabbing and asphyxiation, depending on the relationship between the couple and the place where the events occurred, including the victim's home (Programa Nacional Contra la Violencia Familiar y Sexual, 2019). In the Peruvian context, an investigation into violence against women conducted by Torres (2017) concluded that femicide cases are more frequent in Lima with 452 (35.65\%), followed by Arequipa with $86(6.78 \%)$, Moquegua with four cases $(0.32 \%)$ and Tumbes with eight $(0.63 \%)$. However, another study on emotional dependence in women victims of domestic violence concluded a significant relationship between psychological support and domestic violence in a sample of women who use a national health facility (Aiquipa Tello, 2015).

Likewise, research on depression and anxiety in abused women in the couple's relationship according to the type of cohabitation, in urban-marginal areas of the city of Lima, whose objective was to analyze the relationship between depression and anxiety according to the kind of cohabitation in women with and without abuse in the couple's relationship. The sample applies to 428 women. The design was correlational, transversal, and concluded a significant correlation between anxietystate and depression and significant between depression and anxiety-trait, regardless of the type of relationship (Rosales, Bedón, Díaz, Brioso, \& Pacheco, 2014). Some authors argue that depression in women ranges from 35 to 50 years of age. Even among their results, they allow the analysis and creation of a particular plan to reduce suicide rates because most women are the family's fundamental pillar (Guerrero, 2014). However, other research considers it relevant to highlight that domestic violence is associated with depressive disorder (Moreno, 2014).

There is a relationship between women, men, victims, and behaviors from a cultural standpoint in the male patriarchy's cultural system that will be more vulnerable to perpetrators. In contrast, women are more susceptible to victims. This culture is a representation of past values that regard women only as male companions. In this situation, because justice and gender equality can not be realized only by involving women alone or otherwise. In the modern era, although there are already views for the equation of degrees, there is still a woman's view that is considered weak than men. Victims and perpetrators of violence are potentially performed by both men and women (Rifa'at \& Farid, 2019). Domestic violence includes all physical, sexual, or psychological violence that endangers the safety or wellbeing of a person in the family group; the behavior of people who use both physical force and emotional blackmail; and the threats that lead to the use of physical force, including sexual violence, both in the family and in the home (Ruiz, 2016).

Another definition includes possible manifestations of violence as an imbalance between people in the same family with different types of behavior, from physical to economic abuse (Sheehan, 1997). Violent acts within the family context; it should note that the definition of violence can be physical, sexual, psychological, or based on deprivation or even abandonment (World Health Organization, 2012). Defining physical violence emphasizes that it is any conduct that involves the intentional use of any instrument or procedure to affect another person's body in a way that places the person at risk of physical injury, disease, harm, or pain, regardless of the results of that conduct. According to the Ministry of women and vulnerable population of Peru (2009), the following should 
be considered active: slapping, pushing, hitting, punching, kicking, choking, using objects, weapons, or chemical substances to cause an injury, and passive: deprivation of medical care during an illness or damage (including injuries caused by maltreatment), or intentional failure to warn of clearly physically dangerous situations (loss of car brakes, gas leakage, etc.)

Verbal violence is a form of aggression that often goes unnoticed. It leaves no trace insight; however, injuries caused by this type of abuse are as painful as those issued by physical violence, sometimes even more challenging to heal. It is also necessary to mention that to spill with rude and offensive words is the most obvious form of verbal violence, but not the only manifestation of it. Preferably the verbal abuse includes denigrating names directed towards the other person, which influences the self-esteem and generates double damage: the personal loss on the part of the one who receives it and damage to the relationship between both. The abuser usually denies his behavior, and often this abuse takes place behind closed doors, in a clandestine manner, when the abuser is alone with his victim (Pardilla, 2018).

Psychological violence is considered to be any act performed by a member of the household that distorts a person's affection for him or herself, that harms emotional development, due to repeated insults, humiliation, contempt, lack of motivation, blackmail, isolation from people close to him or her, ridicule, rejection, throwing away objects of value to a person, manipulation, comparisons, or extortion (Ministry of women and vulnerable populations of Peru, 2016). Sexual abuse is understood as any forced sexual intimidation by a partner, whether through threats, intimidation, coercion, or being carried out in a state of unconsciousness or defenselessness (Pardilla, 2018). It includes all types of sexual nature behavior, not limited to vaginal or anal penetration (Ministry of women and vulnerable populations of Peru, 2016). Violence against women or genderbased violence, especially within the family, has a series of implications, the most visible of physical violence. This type of power, as well as any action or inaction that directly or indirectly causes harm or suffering at all levels, mainly in the physical aspect of women, can be external or internal injuries, wounds, bruises, burns, pushing or any other abuse that affects their physical integrity (Zavala \& González, 2018).

Depression, from the Latin, depresses, meaning down, knocked down, is an emotional disorder that, in colloquial terms, presents itself as a state of despair and unhappiness that can be either transitory or permanent (Palacios, 2013); that is why depression is said to be much more than just low spirits. Although most experience sadness from time to time, in some people, these feelings do not go away and are accompanied by other symptoms that cause discomfort or difficulties in carrying out their daily lives. These people may have a disorder called depression. What are its symptoms? The symptoms of depression can vary from person to person. Observable symptoms are low mood, sadness or feelings of hopelessness, or loss of interest in or pleasure from activities enjoyed most days during the past few weeks. Other possible symptoms that occur with some frequency are irritability, crying for no apparent reason. Loss of energy or tiredness, sleep problems, and appetite changes sometimes lead to variations in weight.

Pathological sadness or depression has particular importance in the feeling of impotence in the face of conflicts. The person who suffers from it is confident that whatever he does, he can't change the situation he finds himself so that all hope disappears. In other words, they feel afflicted, depressed, and discouraged, they are not interested in the activities of their environment; they are dull and show little capacity to be favorably moved, but instead tend to cry, to have a single theme and their worries without any way out or hope. According to the Mexican Social Security Institute (2015), discouragement, also known as decay, is a trap that our thoughts set for us when we permit self-pity and let fear cast shadows over everything. This can be overcome by eliminating self-pity, regrets, blaming others, and issuing positive phrases. Affective disorders are pathologies that affect the state of mind and appear at any stage of life or for family conflicts or various causes. These conditions range widely from mild to very severe, and the most common disorders are depression, dysthymia, bipolar disorder, and adjustment disorder, or life crisis (IMQ Amsa, 2018; Palacios, 2013).

In the mild stages, the symptoms are sometimes difficult to detect as they characterize fatigue, loss of appetite, pain in different parts of the body, sleep disturbances, and other symptoms that can be mistaken for a physical illness. In more severe cases, the person has feelings of guilt about 
unimportant things to others, excessive hypochondria or apprehension, risky behaviors, and thoughts of suicide. The main symptoms of depression are intense sadness and lack of motivation for life, which implies a lack of enthusiasm for activities that used to be a source of wellbeing and difficulty in carrying out everyday actions..

\section{METHOD}

The study was of an applied type, with a quantitative approach and a non-experimental design (Hernández, Fernández, \& Baptista, 2014). The population comprises women who suffer from domestic violence, which is infinite due to the lack of updated statistical information because it uses data in one country (Manzano, 1996).

The sample comprises of women over 18 years of age who have been abused and suffer from depressive disorders in three departments of Peru: Lima $(30 \mathrm{~km}$ from the capital), Amazonas (Chachapoyas) (1123 km from the capital), and La Libertad (Huamachuco) $(734 \mathrm{~km}$ from the capital), We located them at the Women's Emergency Centre, in the police stations, the social programs of Vaso de Leche, the canteens and the Office of the Ombudsman for Women, Children, and Adolescents, with a total of 384 women (according to non-probabilistic sample size), distributed as follows: in the province of Lima there were 250 women, La Libertad 80 and Amazonas 54. Researchers traveled to the cities by air and land, coordinating with the authorities in each region to facilitate project implementation. The sample was non-probabilistic for convenience (Otzen \& Manterola, 2017). The sample was selected based on the fact that women over 18 years of age voluntarily participated in the study and were given informed consent, which detailed the objectives, ensuring maximum confidentiality and would only use for research purposes.

The data collection technique was the survey (López-Roldán \& Fachelli, 2015), and the instruments applied were two questionnaires: the domestic violence prevalence scale (FIV J4), which was rated from 0 to 4, with a Likert frequency scale, and for depressive disorder, the Hamilton Scale, whose ratings fluctuated between 0 and 4 and suggested the following cut-off points: not depressed, $\mathrm{mild} /$ minor depression, moderate depression, severe depression, and very severe depression. The researchers for the execution process made the coordination with the institutions in the area for the respective permit. The time used for each research subject varied since it was possible to find illiterate women who were not in the exclusion criteria but were volunteers. Time ranged 10 to 15 minutes for each of the information was susceptible, and each question was a reminder of the tough moments they had lived through or were going through. This happened in all three departments for three months. The complexity lay in each answer given by the research subject, since taking the position of listening and not acting was not within the established.

It should be noted that action had to be taken in a severe case of physical, sexual, and psychological abuse of a woman who was immediately referred to the police station. Activities such as this did not deviate from the proposed objectives for data processing and analysis, version 26 of the SPSS program. The data collected from women who had suffered domestic violence were analyzed and then systematized; the first statistic to obtain was a descriptive analysis, variance, percentages, table of frequencies, and percentiles. Then a second analysis was inferential to verify the hypotheses raised.

\section{FINDINGS AND DISCCUSIONS}

Domestic violence in the three departments of Peru, where research focused on vulnerable women who came to the capital city center. Table 1 shows the percentage of domestic violence, highlighting sexual violence with 24.4\% (Lima), 26\% (La Libertad) and 25.1\% (Amazonas), in second place psychological violence with $19.8 \%$ (Lima), 19\% (La Libertad) and 19.9\% (Amazonas), in third place social violence with 16.1\% (Lima), $16.3 \%$ (La Libertad) and 15.7\% (Amazonas), in fourth place physical violence with 15.8\% (Lima), 15.6\% (La Libertad) and 16\% (Amazonas), in fifth place gender violence with $12.3 \%$ (Lima), $13.8 \%$ (La Libertad) and 13.1\% (Amazonas), and finally patrimonial violence with 11.6\% (Lima), 9.2\% (La Libertad) and 10.1\% (Amazonas). 
100 - Harmoni Sosial: Jurnal Pendidikan IPS

In terms of prevalence, 16 out of every 100 suffer physical violence, 20 out of every 100 suffer psychological violence, 26 out of every 100 suffer sexual violence, 16 out of every 100 suffer social violence, 11 out of every 100 suffer patrimonial violence, and 13 out of every 100 suffer gender-based violence.

Table 1. Domestic Violence in three departments of Peru

\begin{tabular}{lccc}
\hline Domestic Violence & Lima & La Libertad & Amazonas \\
\hline Physical Violence & 15.8 & 15.6 & 16.0 \\
Psychological Violence & 19.8 & 19.0 & 19.9 \\
Sexual Violence & 24.4 & 26.0 & 25.1 \\
Social Violence & 16.1 & 16.3 & 15.7 \\
Petrimonial Violence & 11.6 & 9.2 & 10.1 \\
Gender-based Violence & 12.3 & 13.8 & 13.1 \\
\hline
\end{tabular}

Table 2. Depressive disorder in three departments of Peru

\begin{tabular}{lccc}
\hline Depressive disorder & Lima & La Libertad & Amazonas \\
\hline Intermediate Insomnia & 4.7 & 3.9 & 4.3 \\
Early Insomnia & 7.4 & 7.8 & 7.7 \\
Late Insomnia & 7.5 & 7.3 & 7.7 \\
Work and Activities & 8.0 & 7.4 & 7.7 \\
Depressive Humor & 14.2 & 15.4 & 14.1 \\
Feelings of Guilt & 14.2 & 14.3 & 15.3 \\
Suicide & 14.6 & 14.7 & 15.1 \\
Psychomotor Inhibition & 14.7 & 14.7 & 13.7 \\
Psychomotor Agitation & 14.7 & 14.4 & 15.0 \\
\hline
\end{tabular}

Table 2 shows the percentage of depressive disorder, highlighting psychomotor agitation with $14.7 \%$ (Lima), 14.4\% (La Libertad), and 15\% (Amazonas), in second place psychomotor inhibition with 14.7\% (Lima), 14.7\% (La Libertad) and 13.7\% (Amazonas), in third place suicide with $14.6 \%$ (Lima), $14.7 \%$ (La Libertad) and $15.1 \%$ (Amazonas), in fourth place guilt feelings with $14.2 \%$ (Lima), $14.3 \%$ (La Libertad) and 15.3\% (Amazonas), in fifth place depressive humor $14.2 \%$ (Lima), 15.4\% (La Libertad) and 14.1\% (Amazonas). In sixth place, they suffer in their activities and work $8 \%$ (Lima), 7.4\% (La Libertad) and 7.7\% (Amazonas), in seventh place, late insomnia 7.5\% (Lima), 7.3\% (La Libertad) and $7.7 \%$ (Amazonas), the eighth-place early insomnia 7.4\% (Lima), 7.8\% (La Libertad) and $7.7 \%$ (Amazonas), ninth place intermediate insomnia $4.7 \%$ (Lima), 3.9\% (La Libertad) and $4.3 \%$ (Amazonas).

In terms of prevalence, it is described that 4 out of 100 suffer from intermediate insomnia, 7 out of 100 suffer from early insomnia, 7 out of 100 suffer from late insomnia, 8 out of 100 suffer in the development of their activities and work, 14 out of 100 suffer from depressive mood, 15 out of 100 have thoughts about suicide, 15 out of 100 suffer from psychomotor inhibition and 15 out of 100 suffer from psychomotor agitation. This is observed in the question about depression. At first, the women indicated that they do not suffer from violence, but since each one of them is detailed, and the description of depression is detailed, they chose to indicate that they feel guilty, that they want to cry, but they do not report the fact because they are afraid of abandonment (Zraick, 2018).

The sample of sites studied showed that 14.6\% (Lima), 14.7\% (La Libertad), and 15.1\% (Amazonas) suffered from extreme suicide, which coincided with research on depressive disorders (World Health Organization, 2018). Most of the women studied are between 18 and 59 years of age and live together, consistent with national research on vulnerable populations (Programa Nacional Contra la Violencia Familiar y Sexual, 2019). This research used the Domestic Violence Measurement Scale (VIF J4), concluding that women suffer from domestic violence of all types: physical, psychological, sexual, social, patrimonial, and gender-based. This research coincides with the type and severity of domestic violence (Estévez \& Guandinango, 2018). What can be affirmed is that domestic violence is associated with depressive disorder, which coincides with research on the depressive disorder in women who attend a comprehensive support center (Moreno, 2014). Domestic 
violence is associated with depressive disorder, actions that lead to suicide, according to the report of the people surveyed. This is observed through the results that indicate that they suffer from insomnia in its various stages.

Among the relevant results, it was found that of the $100 \%$ of women who suffer from domestic violence, these are subdivided into physical violence $(16 / 100)$, psychological violence $(20 / 100)$, sexual violence $(26 / 100)$, social violence $(16 / 100)$, patrimonial violence $(11 / 100)$ and gender violence (13/100). For the depressive disorder, it was found that 100 percent of women who suffer from domestic violence have depressive disorders divided into intermediate insomnia (4/100), early insomnia (7/100), late insomnia (7/100), women who suffer in the development of their activities and work (8/100), depressive mood (14/100), thoughts about suicide (15/100), psychomotor inhibition (15/100) and psychomotor agitation (15/100), concluding that domestic violence associated with depressive disorders leads to suicide.

\section{CONCLUSION}

Among the relevant results, it was found that of the $100 \%$ of women who suffer from domestic violence, these are subdivided into physical violence $(16 / 100)$, psychological violence $(20 / 100)$, sexual violence $(26 / 100)$, social violence $(16 / 100)$, patrimonial violence $(11 / 100)$ and gender violence (13/100). For the depressive disorder, it was found that 100 per cent of women who suffer from domestic violence have depressive disorders divided into intermediate insomnia (4/100), early insomnia (7/100), late insomnia (7/100), women who suffer in the development of their activities and work (8/100), depressive mood (14/100),thoughts about suicide (15/100),psychomotor inhibition (15/100) and psychomotor agitation (15/100), concluding that domestic violence associated with depressive disorders leads to suicide

What can be affirmed is that domestic violence is associated with depressive disorder, which coincides with research on depressive disorder in women who attend a comprehensive support center. Domestic violence is associated with depressive disorder, actions that lead to suicide, according to the report of the people surveyed, this is observed through the results that indicate that they suffer from insomnia in its various stages. Domestic violence includes physical, psychological, sexual, social, patrimonial and gender violence, with a similar percentage in the departments under investigation, the characteristics are the same, so it can be concluded that it does not matter where they come from, nor the cultural level, less the age, is the education permeated through the generations. Depressive disorders lead to feelings of guilt and educate their generations in the same way, increasing suicide rates..

\section{REFERENCES}

Aiquipa Tello, J. J. (2015). Dependencia emocional en mujeres víctimas de violencia de pareja. Revista de Psicología (PUCP), 33(2), 411-437.

Estévez, D., \& Guandinango. A. (2018). Tipo y severidad de violencia intrafamiliar en mujeres indígenas de la comunidad de Santa Bárbara-Cotacachi (Unpublished bachelor thesis). Universidad Central de Ecuador, Ecuador.

Guerrero, S. (2014). Depresión en mujeres de 35 a 50 años (Unpublished bachelor thesis). Rafael Landívar University, Guatemala.

Hernández, R., Fernández, C., \& Baptista, P. (2014). Metodología de la investigación McGraw-Hill. México DF.

IMQ Amsa (2018). Trastornos afectivos: Depresión, trastorno bipolar, distimia bilbao. Retreived from https://imqamsa.es/tratamiento/trastornos-afectivos-depresion-ansiedad-trastornobipolar-distimia-bilbao/

López-Roldán, P., \& Fachelli, S. (2015). Metodología de la Investigación social cuantitativa. Barcelona: Universitat Autònoma de Barcelona. 
102 - Harmoni Sosial: Jurnal Pendidikan IPS

Manzano, V. (1996). Acerca de la finitud en las poblaciones. Estadística Española, 38(141), 237244.

Mexican Social Security Institute. (2015). Diagnóstico y Tratamiento del Trastorno depresivo en el adulto.

Ministry of Women and Vulnerable Populations of Peru. (2009). Violencia familiar y sexual en mujeres y varones de 15 a 59 años.

Ministry of Women and Vulnerable Populations of Peru. (2016). Violencia basada en género como marco conceptual para las políticas públicas y la acción de estado.

Moreno, T. (2014). Violencia intrafamiliar como causa de trastorno depresivo en mujeres que acuden al centro de apoyo integral Las Tres Manuelas y al Hospital Cantonal de Sangolquí durante el año 2011 (Unpublished bachelor thesis). Universidad Central de Ecuador, Ecuador.

Otzen, T., \& Manterola, C. (2017). Sampling techniques on a population study. International Journal of Morphology, 35(1), 227-232. doi:https://dx.doi.org/10.4067/S0717-95022017000100037

Palacios, F. (2013). Depresión siglo XXI: temas que bordean la depresión Mental, sus casusas y su manejo. Indiana: Palibrio LLC.

Pan American Health Organization. (2018). La violencia contra la mujer afecta a casi el 60\% de las mujeres en algunos países de las Américas. Retrieved from https://www.paho.org/per/index.php?option=com_content\&view=article\&id=4190:laviolencia-contra-la-mujer-afecta-a-casi-el-60-de-las-mujeres-en-algunos-paises-de-lasamericas\&Itemid $=1062$

Pardilla, V. (2018). El lugar más peligroso para una mujer es su hogar, alerta la ONU: Hoy digital. Retrieved from http://hoy.com.do/la-violencia-verbal/

Programa Nacional Contra la Violencia Familiar y Sexual. (2019). Reporte estadístico de casos con características de feminicidio registrados por los centros emergencia mujer. Retrieved from http://observatorioviolencia.regionica.gob.pe/images/documentos/CEM.pdf

Rifa'at, M., \& Farid, A. (2019). Kekerasan terhadap Perempuan dalam ketimpangan relasi kuasa: Studi kasus di Rifka Annisa Women's Crisis Center. SAWWA: Jurnal Studi Gender, 14(2), 175-190. doi:https://doi.org/10.21580/sa.v14i2.4062

Rosales, R. H., Bedón, M. B., Díaz, C. P., Brioso, A. S., \& Pacheco, E. C. (2016). Depresión y ansiedad en mujeres en situación de maltrato en la relación de pareja según tipo de convivencia, en zonas urbano-marginales de la ciudad de Lima. Theorēma (Lima, Segunda época, En línea), 1, 123-136.

Ruiz, J. (2016). Violencia intrafamiliar. Alicante: Universidad Miguel Hernández de Elche.

Sheehan, K. (1997). Violencia intrafamiliar en hermanos consanguíneos jóvenes adultos.

Torres. R. (2017). Violencia contra la mujer en feminicidio en el periodo 2009- 2014 por regiones en el Perú (Unpublished bachelor thesis). Universidad César Vallejo, Peru.

United Nations Economic Commission for Latin America and the Caribbean (2019). La medición del feminicidio o feminicidio: desafios y ruta de fortalecimiento en América Latina y el Caribe.

World Health Organization (2012). Informe mundial sobre la violencia y la salud. Retrieved from https://www.who.int/iris/bitstream/10665/67411/1/a77102spa.pdf

World Health Organization (2018). Depression. Retrieved form https://www.who.int/mental_health/management/depression/es/ 
Zavala, J. J. A., \& González, E. A. V. (2018). La mujer en Derecho a una Vida libre de violencia desde la Organización Comunitaria. Iustitia Socialis: Revista Arbitrada de Ciencias Jurídicas y Criminalísticas, 3(5), 110-127.

Zraick, K. (2018). El lugar más peligroso para una mujer es su hogar, alerta la ONU. The New York Times. Retrieved from https://www.nytimes.com/es/2018/11/29/feminicidios-en-el-mundoonu/ 